\title{
TEMPO
}

A QUARTERLY REVIEW OF MODERN MUSIC

Edited by Colin Mason

(C) I 962 Boosey \& Hawkes, Ltd.

\section{KODÁLY AT 80}

Information in English on Kodály has been surprisingly scanty, considering how widely some of his works are played and enjoyed. It is only now, in his eightieth year, that we have at last a full-length study in English-from the Hungarian of László Eósze. This book, reviewed in this issue by Frank Howes, has been skilfully translated and adapted for English readers, who will find much in it that is new to them, some of it startlingly. so-such as the account of the contemptuous critical hostility to Kodály before (and sometimes after) the Psalmus Hungaricus, and of the venomous persecution of him from all sides after the collapse of the short-lived communist government of 1919 , under which he had served as acting-director of the Academy of Music in Budapest. These attacks provoked Bartók to a fierce counter-attack, which is reproduced here for the first time in English, and gives us Bartók's word for how much he owed to Kodály-a subject well worth deeper investigation.

Another contribution from Hungary in this issue is part of a chapter on Kodály's melody from a book on him by András Szóllősy, whose work remains the most sustained and penetrating attempt at an analysis of Kodály's style. In the excerpt translated here he resists the too ready attribution of the essential features of Kodály's melody to the influence of folksong. Undoubtedly the contact with folk music was the main liberating influence on Kodály's imagination, but the investigation of this (encouraged by the composer himself), has often been at the neglect of a proper attempt to identify the manifestations in his music of that innate and unique creative genius without which the seed of folk influence would have fallen on barren ground. An example of the kind of study of Kodály's music that is now needed is Cynthia Jolly's article on his original songs-neglected works which are mostly available with adequate English text, and ought to be heard more often. Miss Jolly is herself a distinguished exponent of them (in their original language), and has studied their interpretation with the composer-as Dr. Percy Young, who writes on Kodály's work as an educationist, has similarly been in close contact with the composer in the preparation of the English edition of his 'Choral Method'.

Finally we print here for the first time in English an extended essay by Kodály himself, which gives a valuable picture of the historical background to his own work, and an excellent introduction for the non-specialist reader to a subject which even Hungarian scholars find perplexing-the tangled relations of folk music and art music in Hungarian history. Kodály's own debt to Hungarian art music of the past is worth a separate study, and as a first contribution to such a study we reproduce in facsimile in the art section the piece that inspired the intermezzo in Háry János-perhaps the supreme example of the 'popular' Hungarian style, and an excellent place for someone to begin a study of what is original and what is borrowed in Kodály's art at its greatest. 